\title{
Spermogonial and Aecial Stages of Oat Crown Rust, Puccinia coronata var. avenae, in Japan*
}

\author{
Izumi OKANE** and Makoto KAKISHIMA ${ }^{* * *}$
}

Key words : Puccinia coronata var. avenae, oat crown rust, Avena, Rhamnus, life cycle.

Oat crown rust fungus, Puccinia coronata Corda var. avenae Fraser et Ledingham, is distributed worldwide and forms its uredinial and telial stages on Avena sativa L. and wild oats ${ }^{1,11)}$. In North America and northern Europe, Rhamnus cathartica L. has been known as the most important spermogonial and aecial host plant for the rust fungus ${ }^{10-12}$. In Japan, domestic rhamnaceous species which had been known as important spermogonial and aecial hosts of crown rusts of grasses, Agropyron, Agrostis, Brachypodium, Bromus, Calamagrostis, Elymus, Hierochloe, Holcus, Lolium, Melica, Phalaris, $P o a^{3-6,9)}$, were found not to serve as the spermogonial and aecial host of oat crown rust fungus ${ }^{8)}$ though Narita $^{7)}$ reported that $R$. japonica Maxim. was a spermogonial and aecial host plant of oat crown rust. Even in the case reported by Narita ${ }^{7)}$, no voucher specimens was preserved, therefore, no information on morphological characteristics in the spermogonial and aecial stages of the rust fungus is available for comparative study.

Therefore, in order to clarify spermogonial and aecial hosts of oat crown rust and morphological characteristics of its spermogonial and aecial stages, both domestic and exotic rhamnaceous species were inoculated with the rust fungus. We report here the results of inoculation experiments and morphology of the spermogonial and aecial stages.

Inoculation experiments. Dead leaves of $A$. sativa L. with telia of crown rust were collected in April of 1991 in Kawakami-mura, Minamisaku-gun, Nagano Pref. (TSH-R1104). These materials were kept in a refrigerator at $5^{\circ} \mathrm{C}$ until use. The following ten species were used for inoculation experiments: Rhamnus cathartica L., $R$. cathartica f. dahuricaefolia, R. cathartica var. pubescens Bean, $R$. costata Maxim., R. frangula L., $R$. spathulifolius Fisch. et Mey., R. tinctoria Waldst. et Kit., $R$. utilis Decne., which were grown from seeds and were exotic species except $R$. costata; and $R$. davurica Pall. var. nipponica Makino, R. japonica Maxim., Berchemia racemosa Sieb. et Zucc., which were domestic species and were transplanted from the fields. Teliospores (Plate I-5) on small pieces of the plants $(c a .5 \times 10 \mathrm{~mm})$, which were producing basidiospores, were placed on young leaves of the plants. The plants were kept in moist chamber in darkness at $20^{\circ} \mathrm{C}$ for 2 days and then transferred to a growth cabinet $\left(\mathrm{ca} .20^{\circ} \mathrm{C}\right)$ with controlled artificial illumination.

Results of inoculation experiments are shown in Table 1. Signs of infection were found on leaves of $R$. cathartica, $R$. cathartica f. dahuricaefolia and $R$. tinctoria. Six to 14 days after inoculation, spermogonia were produced on adaxial surface of the leaves of these species, and then, aecia (Plate I-1) were produced on abaxial surface of $R$. cathartica and $R$. cathartica $\mathrm{f}$. dahuricaefolia 13 to 16 days after inoculations. However, aecia were not formed on $R$. tinctoria.

Aeciospores formed on $R$. cathartica by basidiospore inoculations were used as inocula. Aeciospores formed on the plant were dusted on wet filter papers $(5 \times 5 \mathrm{~mm})$, and these were placed on the surface of leaves of oat seedlings, cultivar Zenshin. Then, the plants were treated in the same manner of basidiospore inoculations. As a result, uredinia were produced on the leaves of the plant 1 week after inoculations.

Narita $^{7)}$ reported that the spermogonia and aecia of the oat crown rust were formed on $R$. japonica, and suspected that this species was alternate host plant of the rust fungus in Japan. However, on R. japonica and other domestic rhamnaceous species, no sign of infection was found in our inoculation experiments, while spermogonia and aecia were produced on exotic plants: $R$. cathartica and $R$. cathartica $\mathrm{f}$. dahuricaefolia which have been known as alternate hosts of oat crown rust in North America and Europe ${ }^{10,11)}$. In previous inoculation experiments, the spermogonial and aecial stages of oat crown rust also were not formed on any domestic rhamnaceous species ${ }^{8)}$. Consequently, it is considered that domestic plants of Rhamnaceae do not have susceptibility to oat crown rust, and the spermogonial and aecial stages of the rust fungus are not produced in

\footnotetext{
* Contribution No. 120, Laboratories of Plant Pathology and Mycology, Institute of Agriculture and Forestry, University of Tsukuba

** Institute for Fermentation, Osaka, 17-85, Juso-honmachi 2-chome, Yodogawa-ku, Osaka 532, Japan (財) 発酵研究所

*** Institute of Agriculture and Forestry, University of Tsukuba, Tsukuba, Ibaraki 305, Japan 筑波大学農林学系
} 
Table 1. Results of inoculation experiments with basidiospores from teliospores on Avena sativa collected in Nagano Pref.

\begin{tabular}{|c|c|c|c|c|}
\hline \multirow{2}{*}{$\begin{array}{c}\text { Plant } \\
\text { inoculated }\end{array}$} & \multirow{2}{*}{$\begin{array}{l}\text { Number of } \\
\text { inoculations }\end{array}$} & \multirow{2}{*}{$\begin{array}{c}\text { Number of } \\
\text { positive results }\end{array}$} & \multicolumn{2}{|c|}{$\begin{array}{l}\text { Period (days) required for } \\
\text { the first appearance of }\end{array}$} \\
\hline & & & Spermogonia & Aecia \\
\hline Rhamnus cathartica & 11 & 8 & $6-14$ & $13-16$ \\
\hline $\begin{array}{l}R . \text { cathartica } \\
\text { var. pubescens }\end{array}$ & 1 & 0 & & \\
\hline $\begin{array}{l}\text { R. cathartica } \\
\text { f. dahuricaefolia }\end{array}$ & 2 & 1 & 7 & 15 \\
\hline R. costata & 2 & 0 & & \\
\hline $\begin{array}{l}\text { R. davurica } \\
\text { var. nipponica }\end{array}$ & 5 & 0 & & \\
\hline R. frangula & 3 & 0 & & \\
\hline R. japonica & 2 & 0 & & \\
\hline R. spathulifolius & 1 & 0 & & \\
\hline R. utilis & 1 & 0 & & \\
\hline Berchemia racemosa & 4 & 0 & & \\
\hline
\end{tabular}

a) Aecia not formed.

Japan. Therefore, we suspect that urediniospores are important inoculum for infection of oats in Japan.

Morphology of spermogonial and aecial stages. The spermogonial and aecial stages on $R$. cathartica (TSH-R1102) and those on $R$. cathartica f. dahuricaefolia (TSH-R1101) resulting from inoculation experiments were used for morphological observations. Morphological observations were made by light and scanning electron microscopy (SEM). The spores and hand sections of the sori were mounted in one drop of lactophenol solution on glass slides for light microscopic observation. For SEM, spores from dry herbarium specimens were dusted on double-sided adhesive tape on specimen holders, and coated with gold with an Eiko IB-3 Ion Coater. They were examined with a Hitachi S-430 SEM operating at $20 \mathrm{kV}$.

The spermogonia (Plate I-2) were epiphyllous, densely grouped, subepidermal, and flask shaped (type 4 of Hiratsuka \& Cummins, 1963). Aecia were hypophyllous and capulate with peridia. The aeciospores (Plate I-3, 4) were globose to subglobose, often angular and $16-24 \times$ 13-19 $\mu \mathrm{m}$. The walls were $0.5-1.5 \mu \mathrm{m}$ thick, hyaline, and uniformly and finely verrucose. These morphological characteristics are similar to those of other crown rusts of grasses. However, verrucae on aeciospores were much smaller and more densely distributed than those of others.

Morphological observations of the spermogonial and aecial stages indicated that surface structure of aeciospores of oat crown rust is different from other crown rusts of grasses. It has also been reported that there are several morphological differences between the oat crown rust and others in uredinial and telial stages ${ }^{1)}$. The oat crown rust is different from others in the dimension and the number of germ pore of urediniospores, and the number of paraphysis in uredinia and telia. Its telia are covered by host epidermis for long time after maturation. Furthermore, it has been reported that oat crown rust on Avena could hardly infected to grasses of other genera in inoculation experiments with urediniospores $^{2,7)}$. These results suggest that morphological studies of crown rusts are required to clarify taxonomic position of oat crown rust.

The voucher specimens collected in the field and obtained from inoculations are deposited in Mycological Herbarium, Institute of Agriculture and Forestry, University of Tsukuba (TSH).

We wish to express our thanks to Dr. T. Fukuda, Tokyo Metropolitan Medical Plant Garden, for supplying seeds of plants for our inoculation experiments, and Dr. Y. Ono, Faculty of Education, Ibaraki University, for his valuable suggestions and criticism during the preparation of this manuscript.

\section{Literature cited}

1. Cummins, G.B. (1971). The Rust Fungi of Cereals, Grasses and Bamboos, Springer-Verlag, New York, pp. 141-147.

2. Hiratsuka, N. and Hiratsuka, T. (1956). Studies on the rust-resistance of cereals VI. Susceptibility of various species belonging to Trib. Hordeeae, Bromeae and Agrosteae to the crown rust of oats, Puccinia coronata Corda f. sp. avenae 231. Jpn. J. Breed. 6: 147-155 (in Japanese).

3. Hiratsuka, N., Sato, S. and Kakishima, M. (1984). Summary of the positive results of inoculation experiments with the heteroecious rust fungi in Japan. Rept. Tottori Mycol. Inst. (Japan) $22:$ 9-41.

4. Hiratsuka, N., Sato, S., Katsuya, K., Kakishima, M., Hiratsuka, Y., Kaneko, S., Ono, Y., Sato, T., Harada, Y., Hiratsuka, T. and Nakayama, K. (1992). The Rust Flora of Japan, Tsukuba Shuppankai, Tsukuba, pp. 524530. 
5. Kakishima, M. and Sato, S. (1983). Aecial state of Puccinia coronata on grasses. Ann. Phytopathol. Soc. Jpn. 49 : 399 (Abstr. in Japanese).

6. Kakishima, M., Sato, S. and Katsuya, K. (1979). Uredinial and telial states of Aecidium pulcherimum Ravenel on Berchemia racemosa Sieb. et Zucc. Trans. Mycol. Soc. Japan 20: 41-43.

7. Narita, T. (1972). Studies on crown rust of oats and grasses in Hokkaido and aecia on Rhamnus japonica Max. Proc. Kita-Nippon P1. Prot. Soc. 23 : 25-38 (in Japanese).

8. Okane, I., Kakishima, M. and Katsuya, K. (1990). Host relationships between spermogonial and aecial stages and uredinial and telial stages of Puccinia coronata complex in Japan. Rept. Tottori Mycol Inst. (Japan) 28 : 77-87.

9. Sato, S., Kakishima, M. and Katsuya, K. (1979). Heteroecism of rust fungus, Puccinia erikssonii Bubak. Proc. 23th Ann. Meet. Mycol. Soc. Japan: 85 (Abstr. in Japanese).

10. Savile, D.B.O. (1984). In The Cereal Rust, Vol. I (Bushnell, W.R. and Roelfs, A.P. eds.), Academic Press, New York and London, pp. 79-112.

11. Simons, M.D. (1970). Crown Rust of Oats and Grasses, The American Phytopathological Society, St. Paul.
12. Simons, M.D. (1985). In The Cereal Rust, Vol. II (Roelfs, A.P. and Bushnell, W.R. eds.), Academic Press, New York and London, pp. 131-172.

\section{和 文 摘 要}

岡根 泉・柿島 真：日本産エンバク冠さび病菌Puccinia coronata var. avenaeの精子・さび胞子世代

日本産エンバク冠さび病菌 Puccinia coronata var. avenae の 精子・さび胞子世代宿主を明らかにするため, エンバク上の冬胞 子を用いて国内産抢よび外国産のクロウメモドキ科植物への接 種試験を行った。その結果, 国内産のクロウメモドキ科植物には 感染が認められず, 北米, 北欧においてエンバク冠さび病菌の精 子・さび胞子世代宿主とされている Rhamnus cathartica および R. cathartica f. dahuricaefolia 上にのみ精子器およびさび胞子 堆が形成された。このことから,エンバク冠さび病菌は国内にお いて精子・さび胞子世代を形成せず，その感染にはエンバク上の 夏胞子が重要な役割を果たしているものと考えられる。また, 接 種試験により形成された精子・さび胞子世代の形態観察を行っ た結果, さび胞子の表面には, 他のイネ科植物の冠さび病菌と比 較して小型で密な疮が存在することが明らかとなったため, 他 の胞子世代の形態も含めて, エンバク冠さび病菌の形態学的お よび分類学的再検討が必要であると考える。

(Received February 6, 1995; Accepted March 20, 1995)

\section{Explanation of plate}

Plate I Oat crown rust, Puccinia coronata var. avenae.

1. Aecia (arrow) on Rhamnus cathartica f. dahulicaefolia formed by inoculation (Scale bar: $1 \mathrm{~cm}$ ).

2. A vertical section of spermogonium on Rhamnus cathartica formed by inoculation (Scale bar: $50 \mu \mathrm{m}$ ).

3. Aeciospores (Scale bar: $30 \mu \mathrm{m}$ ).

4. Aeciospores observed under SEM (Scale bar: $5 \mu \mathrm{m}$ ).

5. Teliospores (Scale bar: $30 \mu \mathrm{m}$ ). 


\section{Plate I}

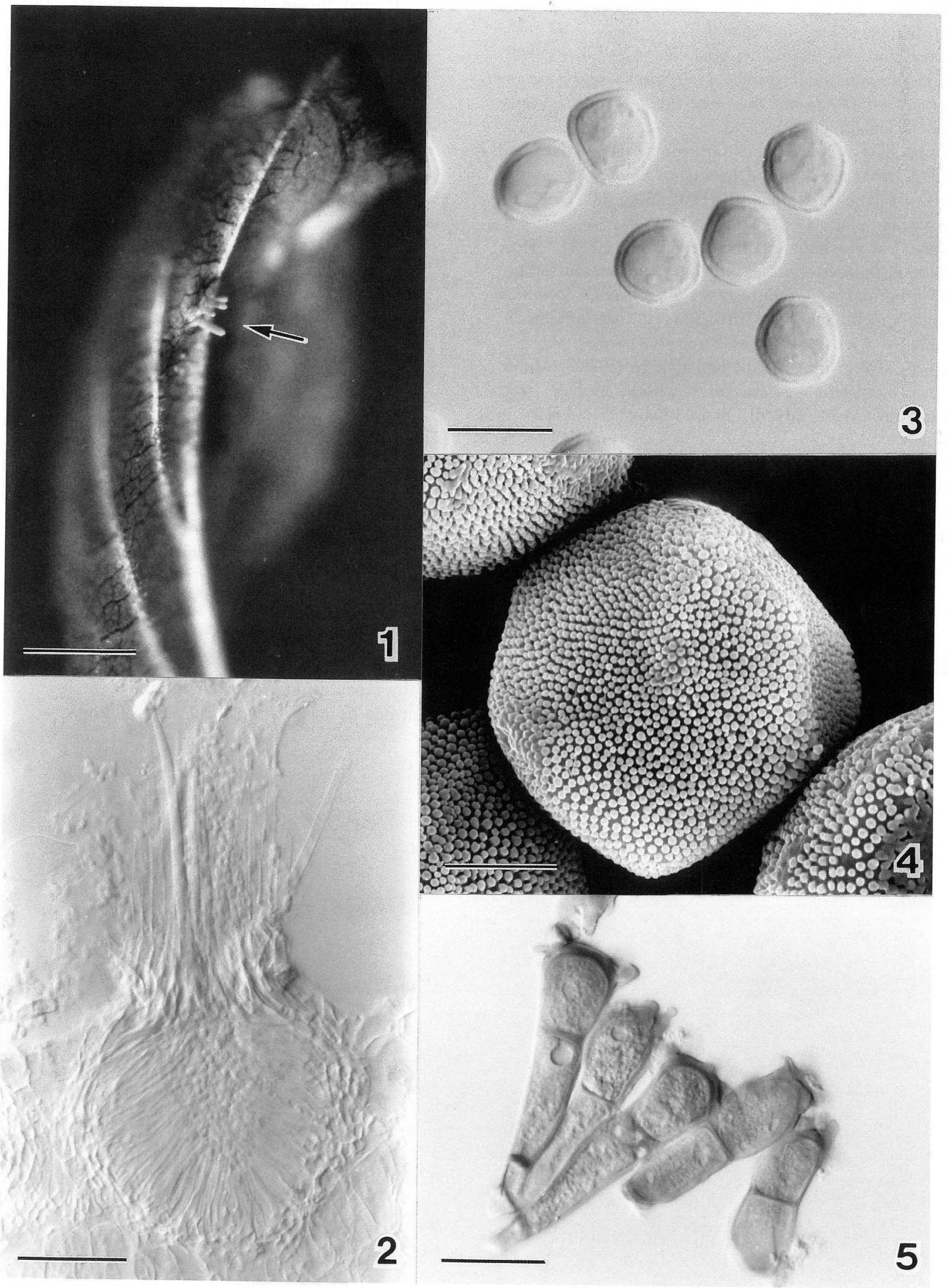

